\title{
The Effect of Dictogloss Technique on Learners' Writing Improvement in Terms of Writing Coherent Texts
}

\author{
Masoome Kooshafar \\ Faculty of Foreign Languages, University of Isfahan, Isfahan, Iran \\ Email: kooshafar.m@gamil.com \\ Manijeh Youhanaee \\ Faculty of Foreign Languages, University of Isfahan, Isfahan, Iran \\ Email: youhanaee_m@hotmail.com \\ Zahra Amirian \\ Faculty of Foreign Languages, University of Isfahan, Isfahan, Iran \\ Email: amirian_z@yahoo.com
}

\begin{abstract}
Considering the communicative framework of language teaching, writing has an advantage- a person can give a variety of information to a close or distant, known or unknown reader or readers. Such way of communicating is highly important in the modern world, whether the communication is in the form of paper-and-pencil writing or advanced electronic writing. Therefore, this skill should be encouraged and nurtured during the language teaching course. Writing consists of different aspects like outline, structure, use of words, etc. which should be considered while teaching and practicing. Among those aspects, one is the focus of this study which is the use of cohesive devices to create a coherent text. Two techniques of teaching these devices, explicit teaching and dictogloss, are evaluated among intermediate Iranian language learners to see which one is more effective in helping them to improve the coherence of their compositions. The conclusion is that both techniques are effective but dictogloss seems to be more useful in case of these participants.
\end{abstract}

Index Terms - dictogloss, explicit instruction, cohesive devices

\section{INTRODUCTION}

One of the productive skills in learning a foreign language is writing. In comparison to the skill of speaking, writing demands more competence, since it lacks immediate feedback from the addressee as a kind of guide. Because of lacking this guide, the writer should anticipate the readers' reaction and try to produce a text that according to Grice (1975) is clear, relevant, truthful, informative, interesting, and memorable. In order to meet the efficacy of this communicative act, linguistic accuracy, clear presentation, and organized ideas should be taken into consideration. Much research has been conducted focusing on all these aspects. They are more or less addressed at all levels of learning a foreign language. In this study organizing ideas is the one which is evaluated under some circumstances. In spite of following linguistic rules and applying highly accurate structures in the text and also suitable choice of words, learners may still have problems in conveying their message clearly. Therefore, it is seen that although some learners, especially the ones at the higher levels of learning, have a good command of English knowledge; they cannot organize and relate their ideas in their texts to create a coherent writing. This lack of connection among ideas lies in the fact that learners cannot use the connecting devices properly.

Halliday and hasan (1976) categorized connecting devices into five groups: lexical cohesion, substitution, reference, ellipsis, and conjunction. While English learners need to learn how to identify and use all these connecting devices, it seems that in order to overcome their main problem in making a smooth interaction with the reader, they need a careful instruction of conjunctions.

Intersentential linguistic devices (Mackay, 1979), markers of cohesion (Cohen, et al. 1979), cohesive conjunctions (Halliday and Hasan, 1976), and discourse markers (Labov, 1972 and Schiffrin, 1987) are other terms which are used for conjunctions.

Xin-hong (2007) found that teaching cohesion in general using some exercises can help Chinese learners improve their writing. He studied all aspects of cohesion except collocations since it is somewhat a vague area to be studied.

Without conjunctions it would be hard to comprehend the connection among ideas. This aspect of writing has been found to be very problematic for English language learners. It was found by Dublin and Olshtain (1980, 3056-62) that 
although native speakers of English can learn and use these cohesive elements as they do other aspects of the language, it seems hard for English language students to master them.

According to Cohen et al. (1979), non-native English speakers had problems with cohesive markers in their reading. Many teachers have seen English learners' compositions as vague and unclear texts because of lacking conjunctions or as a result of inappropriate use of them whether semantically or syntactically.

This lacking or inappropriate use of conjunctions can have different reasons. One of them may be the method of teaching these conjunctions which can be misleading. In fact, many of course books and methods somewhat ignore cohesive devices and offer them to students just as a list of functions not in a comprehensive way. Teachers also teach them mostly out of context and in this way of teaching students cannot recognize the real functions of these conjunctions since presenting a list of cohesive devices does not indicate the logical relationship they can cause among ideas. This will lead to inadequacy of the teaching method which results in lack of knowledge in using the conjunctions appropriately and then creating texts without coherence.

To solve this problem, it seems that teachers should approach and apply a kind of technique which introduces conjunctions to learners in a context-based way. One of these context-based methods is dictogloss which is a new version of dictation first introduced by Wajnryb in 1990. It is a consciousness-raising task which encourages language learners to interact and construct a linguistically acceptable text cooperatively and this text is similar to the one read to them before and they have taken some notes on, both in case of content and style. Therefore, the constructed text is not a replication of the original one since students use their notes, share their ideas with their group-mates, and utilize their own background knowledge to create a text.

The steps followed in dictogloss tasks are described as:

1) Preparation: Students will be prepared for the task by being involved in a discussion and vocabulary presentation related to the topic.

2) Dictation: Teacher will read the text twice at natural speed. Students will take notes while listening in order to be able to reconstruct the text read to them.

3) Reconstruction: Students will be arranged in small groups or pairs. They will pool their notes and reconstruct their own version of the passage. During this step, teacher will not provide them with any information.

4) Analysis/ Feedback: During this stage, students' writings will be corrected first by the teacher just by giving them some codes, and then students will compare their own version with the original one to be informed about their mistakes and be able to correct them.

Swain and her colleague found that dictogloss was effective in helping students internalize their linguistic knowledge by making them aware of language form and function (Kowal \& Swain, 1994).

Lee and Jacobs, in 2001, considered the collaboration aspect of the dictogloss task and based on the journals and questionnaires collected from the students, they found that it has a positive effect on the learners in case of both recognition and effect. They concluded that a collaborative task like dictogloss can help learners be satisfied with working in groups, have better feelings and therefore learn better.

Leow $(1998,51)$ found that when learners direct a task and their exposure to the grammatical points, they are able to improve their accuracy. Therefore, it was concluded that learners' autonomy and negotiation would help learners be more accurate.

Collins (2007) in her article examined the issues of L1 influence and common developmental patterns in the domain of verb tense and aspect. It was found that Dictogloss and interpreting contexts seem to be useful as activities for verb tenses in a Japanese classroom.

Kuiken and Vedder (2003) in their paper evaluated the effect of interaction between learners of English as a second language during a dictogloss task on the acquisition of the passive form. A qualitative analysis made clear that numerous instances of interaction led to the noticing of passive forms.

Different kinds of research, in which dictogloss were used, focused basically whether on the effect of collaboration on learners in this task or grammar, mainly verb tenses, prepositions, adjectives, etc. It seems that this context-based technique has not been utilized to focus more on content especially using cohesive devices as connecting tools of ideas.

This study highlights the effect of applying dictogloss task in English teaching environments on improving learners' compositions in terms of writing coherent texts.

\section{Statement of the Problem}

Based on what was discussed in the introduction, the problem which is going to be examined in this study is how effective a special teaching technique called dictogloss is on learners' writing improvement in terms of coherence. In line with this problem these questions will be answered:

1. Is there a relation between dictogloss technique and learners' writing improvement in terms of writing coherent texts?

2. Which approach is more effective, dictogloss or explicit instruction of cohesive devices?

\section{Methodology}

\section{A. Participants}


The number of participants was 19, both male and female, selected from among language learners at a private Language Institute in Iran, Isfahan. Based on the institute placement test, students who were enrolled at intermediate level classes were selected as participants of this study. They were pre-tested on a composition writing test and were homogenized based on their scores. There were two reasons for selecting these groups of learners. Firstly, it seems that most of the students at this level have an almost enough command of English knowledge to write a text; however, they have a problem in relating the sentences semantically in their writings. They mostly use appropriate vocabulary and correct grammatical sentences, nevertheless, their produced texts are not coherent enough and the expected integration among text elements is lacking. Following many teachers' experiences, this lack of coherence seems to result from unawareness or inappropriate use of conjunctions to link sentences. Secondly, students at lower levels could not take part in this study since their problems are more of vocabulary and correct use of structures. Also, students at higher levels were not suitable either because they are informative enough of both grammatical and semantic use of words to write a coherent and meaningful text.

\section{B. Procedure}

In order to investigate the effect of applying dictogloss technique in classrooms on improving learners' writing coherent texts and also compare it with the traditional way of teaching, which is explicit instruction, an experimental environment was used to carry out this study. Therefore, students were divided in two groups; ten as the dictogloss group and nine as the explicit instruction group. Students in the dictogloss group were introduced to the dictogloss technique beforehand and were familiar with the four steps of this technique.

During the treatment period which lasted for about two months, each week one short text which consisted of some cohesive devices were read twice to the students by the teacher at normal speed. Students took notes while listening and discussed the topic of the text after listening to be sure that they comprehended the text completely in terms of content and vocabulary. Then they started working in pairs to reconstruct the original text. They negotiated and shared their notes and then wrote their own texts. They did not receive any information related to the text from the teacher. After about ten minutes they delivered their texts to the teacher. In order to give a feedback to the students, teacher did not correct any mistakes in their writings, either content-based mistakes or form-based ones. Mistakes were just highlighted by the teacher and the texts along with the original one were given back to students so that they were able to compare them and by using the clues provided by the teacher they could correct their mistakes. This way, students were informed about their lack or misuse of the cohesive devices indirectly. The focus of the feedbacks was mainly on cohesive devices.

In the explicit instruction group, the procedure was like most writing classes in which the teacher chose some cohesive devices similar to those in the short texts used in the dictogloss group. They were taught to the students explicitly by referring to some written examples or by making some statements using those cohesive devices and some exercises related to those conjunctions were done to make sure that the students had learnt their functions and usages. Thus, the mistakes were corrected by the teacher directly and on the spot.

In both groups, students practiced using cohesive devices in their writings during the treatment period which lasted about four consecutive weeks. After this period, all students in both groups were post-tested. For the post-test, students were given a topic to write about. Compositions of the students were scored based on the number of compulsory conjunctions they were supposed to use to write their texts. After ten days, a delayed post-test was run to evaluate whether the effect of treatment after a period of time remained or not. The same procedure in scoring the writings as in immediate post-test was done for the delayed post-test, too. As a result, for each group there were three sets of scores; one for the pre-test and the other two for immediate and delayed post-tests.

\section{Material}

The materials used in this study were taken from a writing course book titled Improve Your IELTS Writing Skills by Sam McCarter and Norman Whitby (2007). It is a complete preparation course for the Academic Writing paper of the International English Language Testing System. All texts were taken from this book. Choice of topic was based on the students' likely interest and background knowledge in that topic. The content was also a concern since the focus of the study was on conjunctions so those texts containing more conjunctions were of priority. Texts were short because students had to remember them and rewrite them, this way, they could keep them in their minds during the process of rewriting. The topics of the texts were kind of clue for the explicit instruction group to teach them how to use the conjunctions.

\section{Scoring and Data Analysis}

To achieve the objectives of this study an experimental method was conducted. There was one experimental group and one control group. Scoring procedure for all pre-test, post-test, and delayed post-test was based on the number of conjunctions used by the students in relation to the compulsory use of conjunctions. As a result, all scores were not out of a pre-determined score like 20 or 100 . The scores were fractions in which the denominators were the number of compulsory conjunctions which students were supposed to use to have a coherent text and the numerators were the number of used conjunctions by the students. Therefore each student's score was different from that of another. Thus, if one student was supposed to use five conjunctions in one composition but had written three, the score was given as $3 / 5$. 
During the same session another student received $1 / 3$ because of fewer numbers of compulsory conjunctions needed to write a coherent text. In order to compare the scores of the students easily, fractions were changed to percentages.

The performance of both groups on the pre-test and immediate and delayed post-tests was analyzed using the statistical procedure of $\mathrm{t}$-Test.

To answer the first research question a paired sample t-test was conducted to evaluate the impact of dictogloss on students' writing improvement in terms of coherence. Table 1 shows the dictogloss group's performance in pre-test and immediate post-test.

TABLE 1:

T-TEST RESULTS FOR DICTOGLOSS GROUP IN PRE-TEST AND POST-TEST

\begin{tabular}{|c|c|c|c|c|c|c|c|c|c|}
\hline & & \multicolumn{5}{|c|}{ Paired Differences } & \multirow[b]{3}{*}{$\mathrm{t}$} & \multirow[b]{3}{*}{$\mathrm{df}$} & \multirow{3}{*}{$\begin{array}{c}\text { Sig. } \\
\text { (2-tailed) }\end{array}$} \\
\hline & & \multirow[b]{2}{*}{ Mean } & \multirow{2}{*}{$\begin{array}{c}\text { Std. } \\
\text { Deviation } \\
\end{array}$} & \multirow{2}{*}{$\begin{array}{l}\text { Std. Error } \\
\text { Mean }\end{array}$} & \multicolumn{2}{|c|}{$\begin{array}{l}95 \% \text { Confidence } \\
\text { Interval of the } \\
\text { Difference }\end{array}$} & & & \\
\hline & & & & & Lower & Upper & & & \\
\hline $\begin{array}{l}\text { Pair } \\
1\end{array}$ & $\begin{array}{l}\text { Pre-test - } \\
\text { Post-test }\end{array}$ & -41.9 & 15.53 & 5.18 & -53.79 & -29.91 & -8.08 & 8 & .000 \\
\hline
\end{tabular}

According to this table, the probability value of pair one, which shows the mean comparison of the scores obtained by the participants of dictogloss group in pre-test and immediate post-test in terms of coherence is $t=-8.08$, and sig= 0 . Therefore, we could claim that regarding the participants performance in terms of coherence in short term, there was a statistically significant difference in students' scores from pre-test to immediate post-test.

Table 2 represents the dictogloss group's performance during a long term period.

TABLE 2:

T-TEST RESULTS FOR DICTOGLOSS GROUP IN IMMEDIATE POST-TEST AND DELAYED POST-TEST

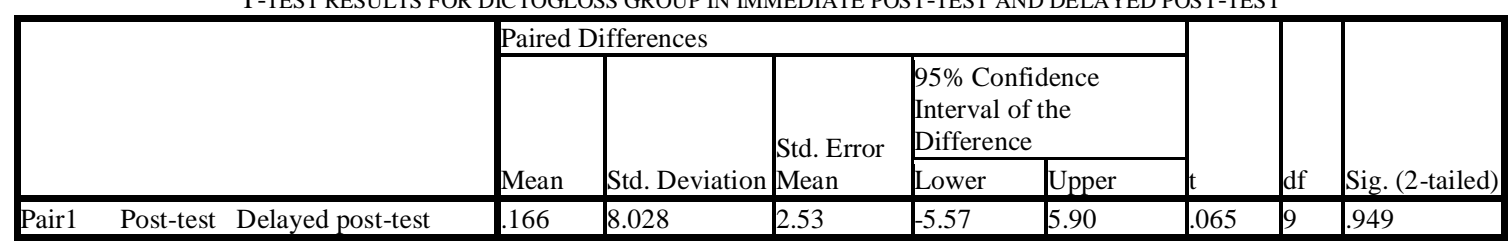

Based on this table, the probability value of pair one, which shows the mean comparison of the scores obtained by the participants of dictogloss group in immediate post-test and delayed post-test in terms of coherence is $t=.065$, and sig=.949. Thus there is no significant difference in students' scores obtained from immediate post-test and delayed posttest. So we can claim that dictogloss method was also effective in improving students' writing ability in terms of coherence in long term.

Table 3 shows the result of T-test comparing the mean scores obtained from the performance of explicit instruction group in short term.

TABLE 3:

T-TEST RESULTS FOR EXPLICIT INSTRUCTION GROUP IN PRE-TEST AND POST-TEST

\begin{tabular}{|c|c|c|c|c|c|c|c|c|c|}
\hline & & \multicolumn{5}{|c|}{ Paired Differences } & & \multirow[b]{3}{*}{$\mathrm{df}$} & \multirow[b]{3}{*}{ Sig. (2-tailed) } \\
\hline & & \multirow[b]{2}{*}{ Mean } & \multirow[b]{2}{*}{ Std. Deviation } & \multirow{2}{*}{$\begin{array}{l}\text { Std. Error } \\
\text { Mean }\end{array}$} & \multicolumn{2}{|c|}{$\begin{array}{l}95 \% \text { Confidence } \\
\text { Interval of the } \\
\text { Difference }\end{array}$} & & & \\
\hline & & & & & Lower & Upper & $\mathrm{t}$ & & \\
\hline Pair 1 & Pre-test post-test & -41.85 & 15.53 & 5.17 & -53.79 & -29.91 & -8.08 & 8 & .000 \\
\hline
\end{tabular}

As it is shown in Table 3, the explicit instruction method seems to be effective in improving learners' writing ability in terms of using cohesive conjunctions to create coherent texts since there is significant difference in the scores of immediate post-test for Group 1; because as it is evident in the Table, the probability value is substantially smaller than the specified critical value for the total scores. $(\mathrm{t}=-8.08$, Sig. $=.0)$ Therefore, the effect of this method is considered positive in short term period.

Table 4 shows the result of T-test comparing the mean scores obtained from the performance of explicit instruction group in long term. 
TABLE 4:

T-TEST RESULTS FOR EXPLICIT INSTRUCTION GROUP IN POST-TEST AND DELAYED POST-TEST

\begin{tabular}{|c|c|c|c|c|c|c|c|c|}
\hline & \multicolumn{5}{|c|}{ Paired Differences } & & \multirow[b]{3}{*}{$\mathrm{df}$} & \multirow{3}{*}{$\begin{array}{c}\text { Sig. } \\
\text { (2-tailed) }\end{array}$} \\
\hline & \multirow[b]{2}{*}{ Mean } & \multirow[b]{2}{*}{ Std. Deviation } & \multirow{2}{*}{$\begin{array}{l}\text { Std. Error } \\
\text { Mean }\end{array}$} & \multicolumn{2}{|c|}{$\begin{array}{l}95 \% \text { Confidence } \\
\text { Interval of the } \\
\text { Difference }\end{array}$} & & & \\
\hline & & & & Lower & Upper & $t$ & & \\
\hline Pair 1Post-test delayed post-test & 6.483 & 12.760 & 4.253 & -3.3251 & 16.291 & 1.5 & 8 & .166 \\
\hline
\end{tabular}

According to Table 4, - in which the probability value is bigger than the specified critical value for the total scores- it is concluded that the method of explicit instruction was effective in long term period as well since there is no significant difference between immediate post-test and delayed post-test. $(\mathrm{t}=1.5$, sig= .166)

Fig. 1 shows the comparison of the results obtained for both groups in the pre-test, immediate, and delayed post-tests.

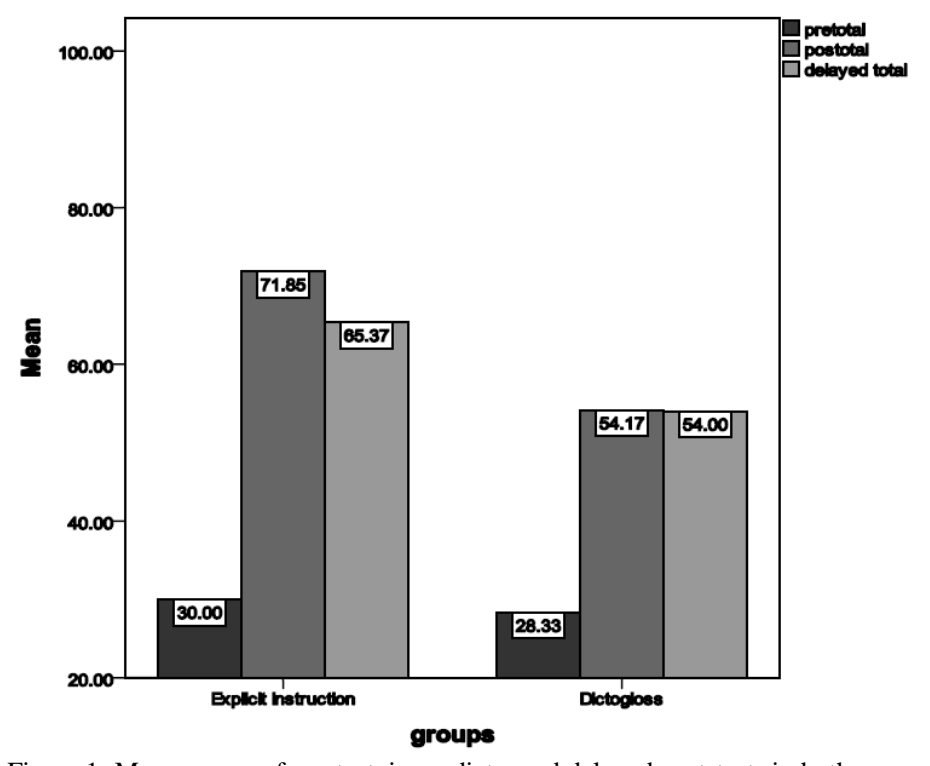

Figure 1: Mean scores of pre-test, immediate, and delayed post-tests in both groups

Fig. 1 shows the mean scores of each test in percentage to clarify the effect of these two techniques on improving students' coherent writing. Since the improvement for the explicit instruction group was $71.85 \%$ in the immediate posttest which is more than that in the other group, explicit teaching proved to be more helpful in increasing students writing ability in terms of coherence. However, dictogloss $(54.17 \%)$ was also a useful task in this regard. Although the mean score of the dictogloss group was lower than that of the other group in immediate post-test, students gained almost the same scores during the delayed post-test. However, in the explicit instruction group, students' scores descended which shows that learning in the dictogloss group was more permanent than that in the explicit instruction group. Therefore, we can claim that dictogloss technique not only can help learners improve their writing skill in terms of coherence, but also it proved to be more effective than explicit instruction technique even though it was an indirect way of teaching cohesive devices.

\section{DISCUSSION AND CONCLUSION}

The aim of this study was to evaluate the effect of dictogloss technique on English learners' writing improvement in terms of using conjunctions. Conjunctions and dictogloss technique are two areas which have been taken into consideration in many studies. Regarding conjunctions, most of the researchers were concerned about either their frequency in writing or speaking or their effect on learners' comprehension (Schleppegrell, 1996, Blagoeva, 2000). In case of dictogloss, most of the concern has been about focus on form in dictogloss or using this task as a collaborative one to see the effect of collaboration on learning English especially tenses (Jacobs, 2001, Leow, 1998, Collins, 2007).

This study, in fact, combined these two areas to find out whether applying dictogloss in English classrooms would be helpful in terms of teaching cohesive devices or not. Based on the scores obtained during the immediate and delayed post-tests (fig. 1) for both explicit instruction group and dictogloss group, it can be concluded that performing dictogloss technique in classrooms can cause less forgetting than teaching students explicitly. Explicit instruction proved to be effective. This is in line with the result obtained by Xin-hong (2007). However, considering a long term period, dictogloss seems to be more helpful since learners' scores were not as lower as those in the other group during the delayed post-test.

Despite these results, some problems and areas that can be further studied should be considered. 
Firstly, the number of participants in this study was limited so maybe the findings cannot be generalized for other learners with other first languages. Further studies can be done both with more number of learners and among learners with other first languages or those who want to learn languages other than English.

Secondly, since conjunctions are very important in conveying the writers' point of view, it seems advisable to conduct the same study for students at lower levels of learning English e.g. pre-intermediate level.

\section{REFERENCES}

[1] Blagoeva, R. (2000). Comparing cohesive devices: conjunctions and other cohesive relations and their place in the BulgarianEnglish interlanguage. Paper presented at Third international conference for research in European studies, Veliko Turnovo, Bulgaria.

[2] Cohen, A., Glasman, H., Rosenbaum-Cohen, P., Ferrara, J., \& Fine, J. (1979). Reading English for specialized purposes: Discourse analysis and the use of student informants. TESOL Quarterly, 13, 551-564.

[3] Collins, L. (2007). L1 differences and L2 similarities: Teaching verb tenses in English. English Language Teaching Journal, 61(4), 295-303.

[4] Dublin, F., Olshtain, T. (1980). The interface of reading and writing. TESOL Quarterly 14: 353-363.

[5] Grice, P.H. (1975). Logic and Conversation. In Syntax and Semantics: Vol. 3 Speech acts, edited by P. Cole and J.L. Morgan. New York: Academic Press

[6] Halliday, M. A. K. \& R. Hasan. (1976). Cohesion in English. London: Longman Group Limited

[7] Kowal, M., \& Swain, M. (1994). Using collaborative language production tasks to promote students' language awareness. Language Awareness, 3(2), 73-93

[8] Kuiken, F. \& Vedder, I. (2002). The effect of interaction in acquiring the grammar of a second language. International Journal of Educational Research, 37(3-4), 343-358.

[9] Labov, W. (1972). Language in the inner city. Philadelphia: University of Pennsylvania Press. (pp. 354-96:"The transformation of experience in narrative syntax")

[10] Lee, L. (2001). Online interaction: negotiation of meaning and strategies used among learners of Spanish. ReCALL, 13(2), 232244.

[11] Leow, R. P. (1998). The effects of amount and type of exposure on adult learners' L2 development in SLA. The Modern Language Journal, 82, 49-68.

[12] Lim, W. L., \& Jacobs, G. M. (2001). An analysis of students' dyadic interaction on a dictogloss task . ERIC Document Reproduction Service No. ED 456649.

[13] Mackay, R. (1979). Teaching the information gathering skills. In R. B. Barkman \& R. R. Jordan (Eds.), Reading in a second language (pp. 254-267). Rowley, MA: Newbury House.

[14] McCarter, S. \& Whitby, N. (2007). Improve Your IELTS Writing Skills. Oxford: Macmillan

[15] Schiffrin, D. (1987). Discourse markers. Cambridge: Cambridge University Press.

[16] Schleppegrell, M. (1996). Conjunction in spoken English and ESL writing. Applied Linguistics, 1 7(3), 271-285.

[17] Wajnryb, R. (1990). Grammar dictation. Oxford: Oxford University Press

[18] Xin-hing, Z. (2007). Application of English cohesion theory in the teaching of writing to Chinese graduate students. US-china Education Review. 4(7), 31-37.

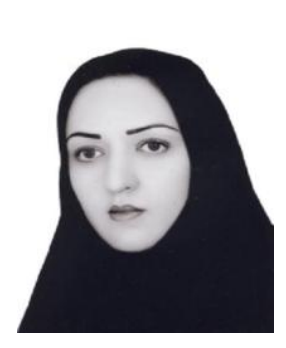

Masoome Kooshafar (b. 1981, Kashan, Iran) is currently getting an M.A. degree at the University of Isfahan, Isfahan, Iran. She received her B.A. in English Literature at Tehran University of Teacher Training (2002). Her main research areas of interest are: Second Language acquisition, Language Teaching Methodology, Discourse Analysis and Pragmatics. She has been working as an EFL instructor since 2002.

Manijeh Youhanaee holds a PhD in language and linguistics from the University of Essex. She has co-authored with Badrizadeh "A Descriptive Dictionary of Theories of Generative Grammar". She has published a number of articles on the teaching/ acquisition of different English syntactic properties by native speakers of Persian. She teaches MA and PhD courses in linguistics, generative grammar, TEFL and SLA. Her areas of interest include syntactic theory, acquisition of L2 \& L3 syntax and issues in teaching and learning English as a second/foreign language.

Zahra Amirian holds a Ph.D. in TEFL from the University of Isfahan, Iran. She is an assistant professor at the University of Isfahan and has taught English to Persian EFL learners for more than ten years. Her research interests are intercultural rhetoric and genre analysis. 